\title{
The Department of Guidance and Counseling Students' Learning Difficulties on Group Counseling Practicum in the Special Region of Yogyakarta
} Tri Sutanti, Suwarjo, Irvan Budhi Handaka, Budi Astuti

AUTHOR CORESPONDENCES:
Tri Sutanti
Universitas Ahmad Dahlan
Jalan Pramuka Nomor 42,Sidikan,
Umbulharjo, Kota Yogyakarta,Daerah
Istimewa Yogyakarta,Indonesia
Email:tri.sutanti@bk.uad.ac.id
Suwarjo
Universitas Negeri Yogyakarta
Jalan Colombo Nomor 1, Kota
Yogyakarta, Daerah Istimewa
Yogyakarta, Indonesia
Email: suwarjo@uny.ac.id
Irvan Budhi Handaka
Universitas Ahmad Dahlan
Jalan Pramuka Nomor 42,Sidikan,
Umbulharjo, Kota Yogyakarta,Daerah
Istimewa Yogyakarta,Indonesia
Email:.irvan.handaka@bk.uad.ac.id
Budi Astuti
Universitas Negeri Yogyakarta
Jalan Colombo Nomor 1, Kota
Yogyakarta, Daerah Istimewa
Yogyakarta, Indonesia
Email: budi_astuti@uny.ac.id
Halaman
7 _ 0

\begin{abstract}
This study aimed to discover the learning difficulties experienced by the guidance and counseling students on group counseling practicum. This study was categorized as a descriptive study involving 286 students of seven Universities in the Special Region of Yogyakarta as the sample of the study. The sample was taken by using purposive sampling technique. The data collection technique of this study was a learning difficulties in group counseling practicum questionnaire by open and closed-ended questions. The data of this study were analyzed by using simple descriptive analysis by calculating the percentage and the categorization of the questionnaire score. The result of the study showed that the most contributing factor to the the students' learning difficulties on the group counseling practicum was the aspect of the lecturer' teaching method by $53.31 \%$. Besides, the result of the open-ended questionnaire showed that lack of group counseling basic skill mastery is one of the difficulties they experience during the group counseling service at the school. It contributes $38.46 \%$. It showed that the practicum teaching methods need improvement to optimize the students' ability in practicing group counseling in school. This study becomes the basic consideration of the needs of learning model for group counseling practicum for the students of guidance and counseling in the Special Region of Yogyakarta.

Keywords: learning difficulties, group counseling, descriptive study
\end{abstract}

\section{INTRODUCTION}

The school counselor is a profession that is expected to assist and support the development of students' potential through psycho-pedagogical guidance and counseling service. The school counselors who are considered as experts shall understand that it is one of their duties and are able to work in a 
team with the teacher and the administrators to develop the learners' character. The Guidance and Counseling possesses several types of service which can optimize the students' character development and assist the students' problem-solving. These services are classified into individual counseling and group counseling service. The group counseling aims to optimize the development of the group member and assist the group member' problem-solving.

A study conducted by Sutanti (2014) found that the factor of the school counselors and the facility of group counseling service hinders the effectivity of group counseling service towards the gifted students in the state senior high school in Yogyakarta. The ineffectiveness of the group counseling service were in the form of unsystematic service stages, less conducive service settings, the time and purpose of service, the types of problem that still focus on the academic area, the strategy of the group counseling that is still in the form of problem lottery, the school counselor' unpreparedness, the absence of service plan, the absence of clear parameter to evaluate the activity, the absence of the instruments for evaluation. Besides, the group counseling service for the gifted students is the same as the regular students, whereas, the gifted students need a specific group counseling service that meets their talents and gifts.

Based on the result of teacher' competence test conducted by the ministry of education and culture in 2012, the school counselor' pedagogical and professional mastery is low. The mean score of the professional competence was only 42 of 100 , while pedagogical competence was 48. Further, based on the teacher' competence test in 2015, the mean score of Indonesian school counselor' pedagogical and professional competence was 53.05 of 100. Based on that data, The enhancement of professional competence involving the guidance and counseling theoretical and praxis framework on the school counselor is crucial.

The development of school counselor' skill and knowledge can be done by developing the school counselor candidate' theoretical and practical competence since the college level. In this case, the role of the Institution that owns the guidance and counseling study program is to develop the school counselor candidate' competence by providing them with the counselor' knowledge and skill in giving guidance and counseling service through practicum activities. This study aims to discover the group counseling learning difficulties on the students of guidance and counseling program of Universities in the Special Region of Yogyakarta. The result of this study is expected to be the basic consideration in designing learning model for group counseling practicum for the students of guidance and counseling program in the Special Region of Yogyakarta.

\section{METHODOLOGY}

This was a descriptive study involving 286 seventh-semester students of seven Universities in the Special Region of Yogyakarta as the participants. The sample was taken by using purposive sampling technique. The seventh-semester students were chosen since they had undergone the group counseling practicum subject and internship program. During the internship program, they had conducted group counseling at school, so they were assumed to understand the difficulties they have faced. This study employed group counseling practicum-learning difficulties questionnaire with open and closed questions to collect the data. The data collection on the factors that affect their learning difficulties focused on the external factors namely lecturer factor, instrumental factor, and curriculum factor. The data of this study were analyzed by using simple descriptive analysis by calculating the percentage and the categorization of the questionnaire score.

\section{RESULT AND DISCUSSION}

The result of the data analysis showed that the most contributing factor of the students' learning difficulties on group counseling practicum was the teaching method. It contributed $53.31 \%$ to the students' learning difficulties. Further, the aspect of unsuitable material division contributed $52.40 \%$, while the practicum instruments contributed $47.65 \%$ towards the students' learning difficulties. The aspect of the lecturers' relationship with the students contributes $47.17 \%$, the aspect of place and laboratory contributes $46.83 \%$, the lecturers' qualification contributes $45.76 \%$, the aspect of un-understandable material contributes $44.56 \%$, and the aspects of material data collection contributes $38.02 \%$. It showed that the practicum teaching methods need improvement to optimize the stu- 
dents' ability in practicing group counseling in school. Figure 1 provides the data of the factors of students' learning difficulties in group counseling practicum in Yogyakarta.

\section{The contribution of each aspect on the students' learning difficulties in Group counseling Practicum}

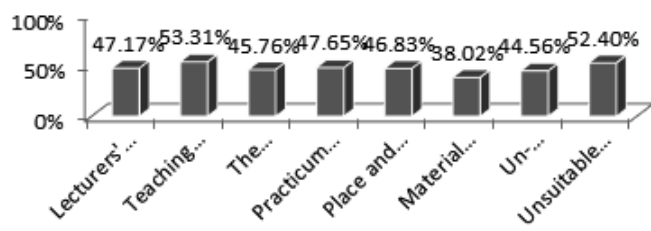

Figure 1

The Factors of the Learning Difficulties in Group Counseling Practicum on the Students of Guidance and Counseling

\section{The Guidance and Counseling students' difficulties in practicing group counseling at school.}

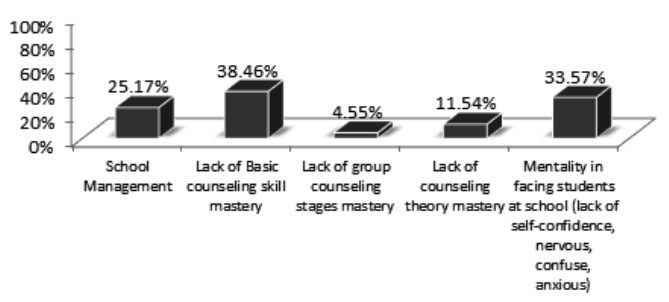

Figure 2

The Guidance and Counseling Students' Difficulties in PracticingGroupCounseling at School

Based on the analysis of open-ended questionnaire with a question "What difficulties do you face in practicing group counseling at school?", Various answers of 286 respondents can be classified into five namely school management, lack of group counseling skill, lack of mastery on the stages of group counseling, lack of mastery on the group counseling theory, and the mental unpreparedness (lack of confidence, nervous, confuse, anxious). Based on the data analysis of the open-ended questionnaire answers, this study found that $38.46 \%$ of the students experienced the learning difficulties on group counseling practicum in the form of lack of group counseling basic skill and 33.57\% in the form of mentality in facing the students at the school.
Moreover, the $25.17 \%$ of learning difficulties were in the form of school management, $11.54 \%$ in the form of lack of counseling theory mastery, and $4.55 \%$ were in the form of lack of counseling stages mastery. Based on that data, it is found that the students of Guidance and Counseling program in the Special Region of Yogyakarta need a practicum subject that can develop the group counseling basic skill and give mental preparation to face the real counselees at school. The result of data analysis of group counseling practicum based on the open-ended questionnaire is provided in figure 2 .

This study proved that the students' learning difficulties are caused by the external factors. According to Dimyati and Mudjiono (2013), there are two factors of learning difficulties, internal and external factors. The internal factors cover the learning attitude, motivation, concentration, organization, storing learning result, discovering the stored learning result, achievement skill, self-confidence, intelligence, learning habit, and the students' future goals. The external factors include teacher, learning facility, scoring policy, school social environment, and school curriculum. In line with Syah (2012), the factors that cause learning difficulties consist of two types namely: Learners' internal factor, it is the conditions or situations emerge from the learners internal. Learners' external factor, it is the conditions or situations come from the learners' surrounding. External factors include family, social environment, and school environments such as poor school building location, teachers' condition, and low-quality learning instruments.

This study emphasizes that the early improvements on the group counseling practicum are vital to minimize the learning difficulties when practicing group counseling at school during the internship. The guidance and counseling possess several services in the individual and group settings. One of its types is group counseling service. Group counseling service possesses advantages where the group members have the chance to solve their problems through interaction with other members and is assisted by a counselor. According to Corey (2012), " group counseling has preventive as well as remedial aims. The counseling group has specific focus which may be educational, career social and personal. Group works emphasize interpersonal com- 
munication of conscious thought, feelings, and behavior within here and now time frame. Counseling group are often problem-oriented, and the members largely determine their content and aims.".

The group counseling practicum is essential since it is a crucial service for the adolescents. Most of the Indonesian school counselor face teenage counselees since most of them are junior high school and senior high school counselor. In line with Jacob (2006), for some people, group counseling is better than individual counseling because the group member needs other members' suggestions, they also learn to listen and respect rather than only speaking. The counselor must master this service since it assists the counselees or students improving their achievement (Caroll et al., 2009). In the adolescents' environment, group counseling is better than the individual counseling since they like to talk to the other adolescents rather than talk to the adults (Widaryati, 2013). Group counseling is essential since it can develop students' interpersonal skills and selfefficacy(Ikawati, 2015).

This study showed that out of 286 students of guidance and counseling program, there were $4.55 \%$ of students who experience difficulties in practicing counseling stages. Therefore, the lecturers need to implement more applicative teaching method to teach counseling stages. According to Jacob(2006), "Group counseling consists of three stages, the beginning stage, the working stage, and the terminating stage." Besides, he states that "the beginning stage may bethe last part of the first session, the entire first sessions or the first couple of session. It is not uncommon for the members of certain groups to take more than two sessions to feel enough trust and comfort to share beyond the surface level. For instance, it may take groups in prison or residential treatment center for teenagers as many as three sessions to develop an atmosphere that lends itself to productive group work". In the working stage, the group members focus on the expected goal. In this stage, the group members learn new material through discussion of various topics, doing an assignment, and the sense of being the part of the group. This stage is the core of the activities, where the group members gain many benefits during the process. During the closing stage, the counselor facilitates the group members to share what they have got, how the changes they have experienced, and their plan in applying their obtained experience in daily life. The group members say goodbye and agree to terminate the group activity.

The students need to learn the important point of each counseling stage to develop their group counseling skills. Natawidjaya (2009) states that there are three stages in group counseling the counselor need to master namely: The beginning stage, in this stage the counselor introduce, involve, and incorporate the members into group life. In the middle of group counseling stage, it includes the discussion, opinion and experience sharing, problem-solving or doing assignments. The ending stage of the group counseling is the closing stage. In this stage, the counselor needs to conclude the activities done in the previous stages. In this study, the factor of lack of group counseling basic skill mastery dominates the cause of students' learning difficulties by $38.46 \%$. As a professional, a counselor must master the basic counseling skill. Therefore, the students of the guidance and counseling program as the counselor candidate must master the basic counseling skill both in individual or group settings. Minimal mastery of basic counseling skill leads to the minimum contribution of school counselor (Carrell, Scott E. \& Mark, 2014).

To be a professional helper, a counselor must at least master some basic counseling skill used in the opening, main, and closing stage of the service process. This can be done since they are in counselor candidate education. The counselor candidates must be trained by some skills of each stage of group counseling so they can give a professional service. Jacob (2006) explains that there are some basic counseling skills that a counselor needs to master in a group counseling activity. Those skills are active listening, reflection, clarification and questioning, summarizing, linking, mini-lecturing and information giving, encouraging and supporting, tone setting, modeling and selfdisclosure, use of eyes, use of voice, use of the leader's energy, identifying allies, and multicultural understanding.

This study found that the most dominant factor that contributes on the students' learning difficult was the lecturers' ineffective teaching method. It contributes $53.31 \%$ towards their learning difficulties. Based on the open-ended questionnaire, this study found that the lack of group counseling basic skill mastery contributes 38\% on their learning difficulties. The group counseling is a service that the 
counselor must master. The group counseling practicum shall be given in the form of the factual learning process so the students can learn group counseling as early as possible. Based on that data, it is found that the students of Guidance and Counseling program in the Special Region of Yogyakarta need a practicum subject that can develop the group counseling basic skill and give mental preparation to face the real counselees at school. One of the methods can be developed is early clinical exposurebased group counseling practicum learning model to develop the counselor candidate competencies in giving the group counseling service for the students.

Early Clinical Exposure is a learning method that gives the students opportunity to experience factual learning. It is a learning method where the students are introduced to the clinical condition regarding the material being learnt. In the guidance and counseling settings, clinical means the regular and inclusive school scope and the social institution such as drug rehabilitation institution and social environment such as disaster victims.

According to Motilal (2014), Education system across the world now emphasise early clinical exposure towards horizontal and vertical integration and contextual learning in the local settings. BitaAfra et al. (2015) state that Early exposure of medical students to clinical experiences will enhance their professional socialization process and will provide effective learning along with understanding. Early exposure to a clinical medicine program helps new students to cope with tension and job stress and improves their awareness of their profession.According to Rawekar et al. (2016), Early clinical exposure provides the students various patient load does not pose a problem in the Indian setting. In fact, it possesses additional advantage to the students for a new experience and leads to deep learning. The study conducted by BitaAfra et al (2015) found that the experimental group who is given early clinical exposure showed awareness of the profession' role and responsibility, sensitivity towards the patient' problem, understanding the medical limitedness, interested on the educational material, familiar with the future workplace, and believe on their profession. Those studies showed that practical learning methods assist the students in facing the real problem and makes them more prepared to enter the professional world. It is in line with the result of the study that found a group counseling learning method by providing the students with the fake problem, and fake counselee leads to some difficulties when facing real counselees at school.

This study shows that the ability of counselors in providing group counseling services still needs to be improved through the development of a model of group counseling lectures. Group counseling services need to be taught and mastered by prospective counseling and counseling teachers or counselors because group counseling services have a number of advantages. Group counseling had significant effects on the psychosocial behavior of people living with HIV / AIDS (Ushie, Onongha, Emeka, \&Lasisi, 2012). School psychologists are interested in providing effective and efficient direct services to children, group counseling represents one viable and valuable intervention (Crespi, 2009). Effective group counseling is also to reduce depression and traumatic (Mpungu, Et al., 2013). Group counseling is also useful for addressing issues related to emotional issues, sexual issues, stress management, study skills, and diversity (Bore, Hendricks, \&Womack, 2013).

\section{CONCLUSION}

This study found that the most dominant factor that contributes on the students' learning difficulties was the lecturers' ineffective teaching method. Based on the openended questionnaire, this study found that the students experience difficulties in mastering group counseling basic skill. This study proved that the practicum teaching methods need improvement to optimize the student's ability in practicing group counseling in school. This study becomes the basic consideration on the needs of learning model for group counseling practicum for the students of guidance and counseling in the Special Region of Yogyakarta. One of the alternative learning models is early clinical exposure-based group counseling practicum model. This study suggests the future researcher discover effective practicum model to develop the competencies of the guidance and counseling students in giving group counseling service.

\section{REFERENCES}

Bhattacharya, S. N., Malgaonkar, A. A., \&Kartikeyan, S. (2017). Early ClinicalExposure to First Year 
MedicalStudentsThroughCase BasedLearning in EndocrinePhysiology. International Journal of Research in Medical Sciences, 4(6), 2355-2358.

Bita, Afra.,Alizadeh,Mahasti.,Taghavi, Simin., Bayrami,HosseinJabbari., Yari, Javaher.(2015). The Impact of Early Clinical Exposure on the Knowledge and Attitude of Basic Sciences Medical Students at Tabriz University of Medical Sciences. Journal Rev Dev Med Educ, 4 (1), 55-60.

Bore, Samuel. K., Hendricks, LaVelle., Womack, Ashley., (2013).Psycho Educational Groups in Schools: The Intervention of Choice. Journal of Counseling and Addiction, 2 (1).

Caroll, A., Houghton, S., Wood, R., Unsworth, K., Hattie, J., Gordon, L., \& Bower, J. (2009). Selfefficacy and Academic Achievement in Australian Hight School Student: The Mediating Effects of Academic Aspirations and Delinquency. Journal of Adolescence, 3 (2):797-817.

Carrell, Scott E. \&Hoekstra, Mark. (2014) Are School Counselors an Effective Education Input?.Economics Letters Journal, 12(5), 66-69.

Corey, Gerald. (2012). Theory and Practice of Group Counseling.Eighth edition. USA: Broks/Cole Thompson

Crespi, Tony.D. (2009). Group Counseling in the Schools: Legal, Ethical, and Treatment Issues in School Practice. Psychology in the Schools, 46 (3).

Dandekar, K. (2014). The Impact of Early Clinical Exposure on First MBBS Students. International Journal of Healthcare and Biomedical Research, 2(4), 176-81.

Ikawati, Mei PD.(2015). Upaya Meningkatkan Konsentrasi Belajar Siswa KMS (Kartu Menuju Sejahtera) Menggunakan Konseling Kelompok bagi Siswa. Psikopedagogia Jurnal Bimbingan dan Konseling, 4(2).

Jacob, Ed. (2006). Group Counseling Strategies and Skill. FivethEdition. USA: Broks/Cole Thompson

Mpungu, Etheldreda Nakimuli.,Okello, James., Kinyanda, Eugene., Alderman, Stephen., Juliet nakku., Alderman, JeffreyS., Pavia, Alison., Adaku, Alex., Allden, Kathleen., Musisi, Seggane.(2013). The Impact of Group Counseling on Depression, Post-Traumatic Stress and Function Outcomes: A Prospective Comparison Study in the Peter C. Alderman Trauma Clinics in Northern Uganda. Jour- nal of Affective Disorders, 17 (3).

Natawidjaya, Rochman. (2009). KonselingKelompok, Konsep Dasar danPendekatan. Bandung: Rizqi Press

Patil, P. G., Ueda, T., \& Sakurai, K. (2016). Influence of Early Clinical Exposure for Undergraduate Students on Self-perception of Different Aspectsof Geriatric Dental Care: Pilot Study Between two Colleges from JAPAN and India. The Journal of Indian Prosthodontic Society, 16(3),288.

Rawekar, Alka., ArunitaJagzape., TriptiSrivastav., \& Shashank Gotarkar.(2016). Skill Learning Through Early Clinical Exposure: An Experience of Indian Medical School.Journal of Clinical and Diagnostic Research. 10(1), 1-4.

Sawant, S. P., \& Rizvi, S. (2015). Importance of Early Clinical Exposure in learning Anatomy. Journal of Applied Medical Sciences, 3(2).

Shigli, K., Nayak, S. S., Sankeshwari, B., Fulari, D., Chopade, S., Wadgave, U.,\&Murugaboopathy, V. (2017). Effectiveness of an Early Clinical Exposure Module on the Performance of Second Year Dental Students-A Randomized Controlled Study. Annals of Medical and Health Sciences Research, 7(4).

Sutanti, Tri. 2014. Pelaksanaan Layanan Konseling Kelompok untuk Anak Cerdas Istimewa di SMA Negeri Kota Yogyakarta. Jurnal Gusjigang, 1(1), 110 124.

Ushie, Michael A., Onongha, Grace I., Emeka, Josepha. O., \&Lasisi, Chidinma.J. (2012) Analysis of the Effect of Group Counseling on the Copping Behavior of People Living with HIV/AIDS in Yakurr Local Goverment Area. Cross River State. Journal Academic Reseach International, 3 (2).

Vyas, R., \&Sathishkumar, S. (2012). Recent Trends in Teaching and Learning in Physiology Education Early Clinical Exposure and Integration. International Journal of Basic and Applied Physiology, 1(1), 175-181.

Widaryati, Sri (2013). Efektivitas Pengaruh Konseling Kelompok Terhadap Efikasi Diri Siswa. PSIKOPEDAGOGIA Jurnal Bimbingan dan Konseling, 2(2). 94-100. 